\title{
Position-Independent, High-Level Expression of the Human $\beta$-Globin Gene in Transgenic Mice
}

\author{
Frank Grosveld, Greet Blom van Assendelft, \\ David R. Greaves, and George Kollias \\ Laboratory of Gene Structure and Expression \\ National Institute for Medical Research \\ The Ridgeway, Mill Hill \\ London NW7 1AA, England
}

\section{Summary}

We have constructed a "minilocus" that contains the 5' and $3^{\prime}$ flanking regions of the human $\beta$-globin locus and the $\beta$-globin gene. These regions are characterized by erythroid-specific DNAase I-superhypersensitive sites and are normally located approximately $\mathbf{5 0}$ kb $5^{\prime}$ and $20 \mathrm{~kb} 3^{\prime}$ of the $\beta$-globin gene. This minilocus is expressed tissue-specifically in transgenic mice at a level directly related to its copy number yet independent of its position of integration in the genome. Moreover, the expression per gene copy is the same in each mouse and as high as that of the endogenous mouse $\beta$-globin gene. These results indicate that the DNA regions flanking the human $\beta$-globin locus contain dominant regulatory sequences that specify position-independent expression and normally activate the complete human multigene $\beta$-globin locus.

\section{Introduction}

The human $\beta$-like globin genes are a cluster of five active genes, in the order $5^{\prime}-\varepsilon_{-} G_{\gamma}-A_{\gamma}-\delta-\beta-3^{\prime}$, comprising approximately $60 \mathrm{~kb}$ of DNA on the short arm of chromosome 11 . The different genes are expressed in a developmentalstage- and tissue-specific manner, i.e., the embryonic $\varepsilon$ gene is expressed in the yolk sac, the fetal ${ }^{G_{\gamma}} \gamma$ and $A_{\gamma}$ genes are expressed primarily in the fetal liver, and the adult $\delta$ and $\beta$ genes are expressed primarily in bone marrow (for review, see Maniatis et al., 1981). Mutations in this gene family lead to a broad spectrum of genetic diseases; a large number of these mutations have been characterized, ranging from simple amino acid changes by point mutations to complete deletions of the locus (for review, see Collins and Weissman, 1984). These often lead to severe clinical problems and early death. Conventional treatment of these diseases (by transfusion) is costly, risky, and in many cases inadequate. Since bone marrow is accessible, this type of disease is a prime candidate for "gene therapy" (Hock and Miller, 1986). A number of laboratories, including our own, have made progress in delineating the cis-acting DNA sequences necessary for the transcription of the $\beta$-globin gene, using DNA-mediated gene transfer both in tissue culture cells-in particular, murine erythroleukaemia (MEL) cells-and in transgenic mice.

It is clear that the DNA sequences regulating the human B-globin gene are located both $5^{\prime}$ and $3^{\prime}$ to the translation initiation site (Wright et al., 1984; Charnay et al., 1984).
Using MEL and K562 cells we have now identified at least four separate regulatory elements required for the appropriate expression of the human $\beta$-globin gene: a positively acting globin-specific promoter element, a putatively negative regulatory promoter element, and two downstream regulatory sequences (enhancers), one located in the gene and one approximately $800 \mathrm{bp}$ downstream of the gene (Antoniou and Grosveld, submitted). A similar enhancer has also been identified downstream of the chicken $\beta$-globin gene in cultured chicken erythroid cells (Hesse et al., 1986; Choi and Engel, 1986). The downstream enhancer has been shown to be a developmentalstage-specific enhancer by using transgenic mice (Kollias et al., 1986, 1987; Behringer et al., 1987). All of these results therefore indicate that multiple developmentalstage-specific control regions of the $\beta$-globin gene are located immediately $5^{\prime}$, inside, and $3^{\prime}$ of the $\beta$-globin gene. However, when a $\beta$-globin gene containing all of these control regions is introduced into transgenic mice, the gene is never expressed at the same level as the mouse $\beta$-globin gene, and exhibits position effects. This is characterized by a highly variable expression of the transgene that is nol correlated with the copy number of the injected gene in the mouse genome. The same phenomenon has been observed with almost all the genes that have been studied in transgenic mice (Palmiter and Brinster, 1986). Moreover, in the case of $\beta$-globin the level of expression of each injected gene is at best an order of magnitude below that of the endogenous mouse gene (Magram et al., 1985; Townes et al., 1985; Kollias et al., 1986). A similar problem is observed when the $\beta$-globin or other genes are introduced into cultured cells by transfection or retroviral infection. This poses a big problem in the context of gene therapy by gene addition in stem cells. Our tentative interpretation of this position effect is that the injected DNA does not have sufficient sequence information to be independent of the effect of the integration locus.

The strongest evidence for the existence of such control sequences has come from the analysis of human $\gamma \beta$ thalassemias (Van der Ploeg et al., 1980; Curtin and Kan, 1987). Patients with Dutch thalassemia are heterozygous for a large deletion that removes $100 \mathrm{~kb}$ upstream of the $\beta$-globin gene but leaves the $\beta$-globin gene, including all of the control regions described above, intact (Kioussis et al., 1983; Wright et al., 1984; Taramelli et al., 1986). Since the patient is heterozygous and transcribes the normal locus in the same nucleus, some control mechanism must override the functioning of the control sequences immediately surrounding the genes in the mutant locus. In the case of the Dutch $\gamma \beta$-thalassemia, it could indeed be shown that the mutant locus is in an inactive chromatin configuration and has a classical position effect (Kioussis et al., 1983). Possible candidate sequences for activation control are the regions upstream of the $\varepsilon$-globin gene and downstream of the $\beta$-globin gene, which contain a number of "superhypersensitive" sites. These sites are more sensi- 


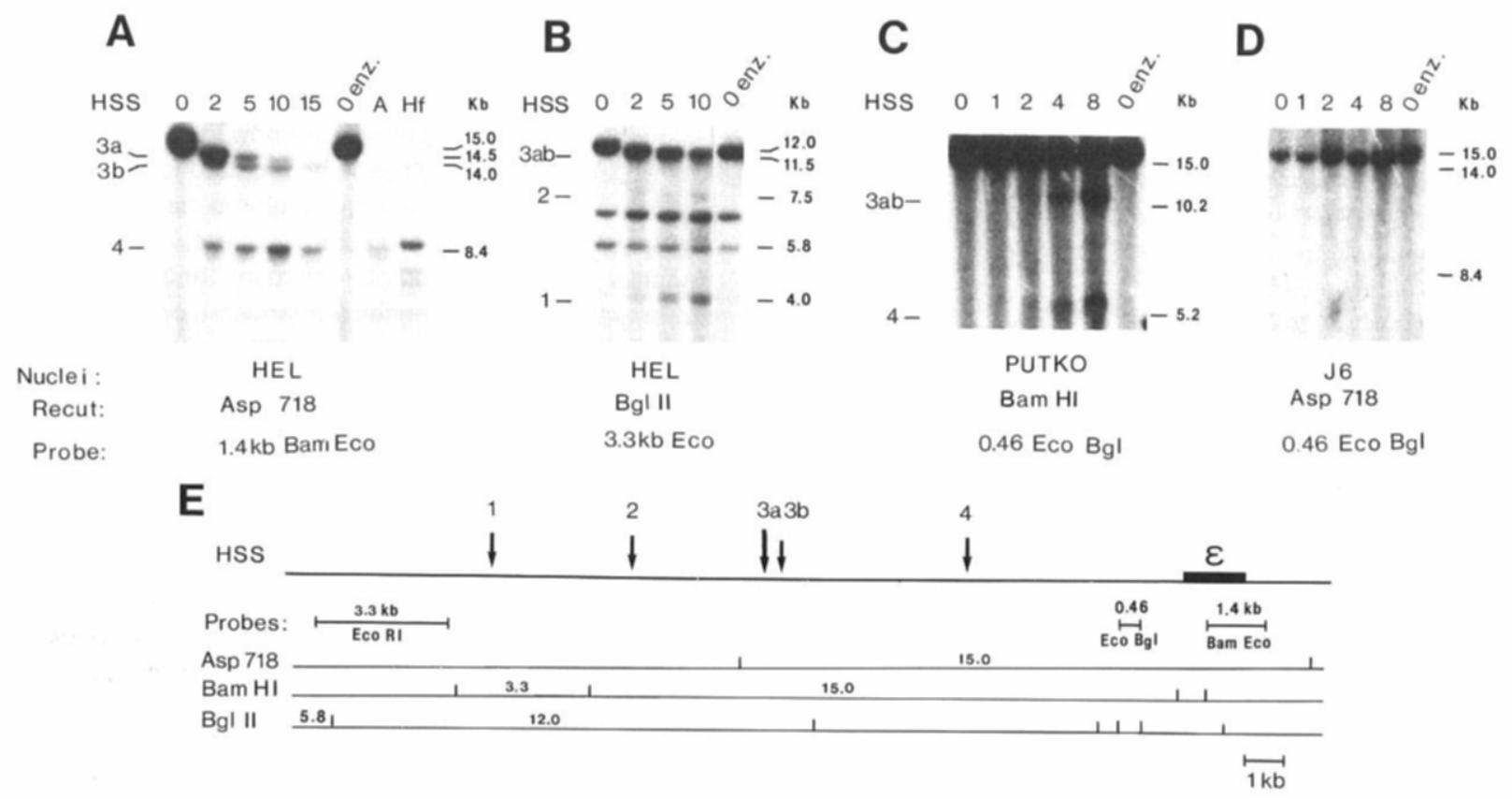

Figure 1. Mapping DNAse I-Hypersensitive Sites $5^{\prime}$ of the $\varepsilon$-Globin Gene

(A) Nuclei of HEL cells were incubated with DNAase I $(60 \mu \mathrm{g} / \mathrm{ml})$ at $37^{\circ} \mathrm{C}$, and aliquots were removed from the reaction at the times indicated (in $\mathrm{min}$ ) above the lanes. Control aliquots of approximately $10^{7} \mathrm{HEL}$ nuclei were incubated in the absence of DNAase I $(0$ enz.) or in the presence of 30 units of Alul (A) or 60 units of Hinfl $(\mathrm{Hf})$ for $15 \mathrm{~min}$ at $3 \mathrm{~J}^{\circ} \mathrm{C}$. DNA was puritied atter proteinase $\mathrm{K}$ digestion, recut with Asp718, fractionated on a $0.6 \%$ agarose gel, transferred to nitrocellulose, and probed with an $\varepsilon$-globin gene probe (BamHI-EcoRI $1.4 \mathrm{~kb}$ ). Hypersensitive sites (HSSs) are indicated at left; see (E).

(B) The DNAase I-digested samples of (A) were recut with Bglll and probed with a $3.3 \mathrm{~kb}$ EcoRl fragment that detects, in addition to 12.0 and 5.8 $\mathrm{kb}$ bands, a cross-hybridizing band of $6.8 \mathrm{~kb}$ after filters are washed at a stringency of $0.3 \times \mathrm{SSC}$ at $65^{\circ} \mathrm{C}$. This fragment is not observed after washing in $0.1 \times \mathrm{SSC}$ at $65^{\circ} \mathrm{C}$ (not shown)

(C) Nuclei of PUTKO cells were digested with DNAase I $(20 \mu \mathrm{g} / \mathrm{ml})$ at $377^{\circ} \mathrm{C}$, and samples were removed from the reaction after $1,2,4$, and $8 \mathrm{~min}$, as indicated. A control aliquot of approximately $10^{7}$ nuclei was incubated for $8 \mathrm{~min}$ at $37^{\circ} \mathrm{C}$ in the absence of DNAase I $(0$ enz.). After recutting of the DNA with BamHI, gel electrophoresis, and transfer to nitrocellulose, the filter was hybridized with a $0.46 \mathrm{~kb}$ EcoRI-BgllI probe and washed at a final stringency of $0.3 \times \mathrm{SSC}$ at $65^{\circ} \mathrm{C}$.

(D) Nuclei of human T cell line J6 were digested with DNAase $1(20 \mu \mathrm{g} / \mathrm{ml})$ at $37^{\circ} \mathrm{C}$ for the times indicated (in min). After recutting of the DNA with Asp718, gel electrophoresis, and transfer to nitrocellulose, the filter was hybridized with the $0.46 \mathrm{~kb}$ EcoRI-Bglll probe and washed in $0.3 \times \mathrm{SSC}$ at $65^{\circ} \mathrm{C}$. That DNAase I digestion had occurred was shown by reduction of the size average of bulk DNA and the appearance of DNAase I-hypersensitive sites around T-cell-specific genes (not shown).

(E) Shows a restriction map of the ß-globin locus upstream of the $\varepsilon$-globin gene for the three restriction enzymes used in these experiments. Locations of probes and deduced positions of DNAase I-hypersensitive siles (numbered) in HEL and PUTKO cell chromatin are marked.

tive to DNAase I digestion than the hypersensitive sites found in and around the individual genes during gene expression (Tuan et al., 1985; Forrester et al., 1986; Groudine et al., 1983). In addition, they are erythroid-cellspecific and are present when any one of the globin genes is expressed. We have tested the possible role of these sequences by using transgenic mice, and we show that these sequences can be used to obtain completely regulated, high-level $\beta$-globin gene expression independent of the position of the transgene. We discuss the role of these sequences and propose a model for the mechanism of globin switching during development.

\section{Results}

The rationale behind the experiments was provided by the position effects observed in certain thalassemias (Kioussis et al., 1983) and after injection of small $\beta$-globin constructs in transgenic mice (Magram et al., 1985; Townes et al., 1985; Kollias et al., 1986). The aim therefore was to establish whether dominant control regions are present in the flanking regions, by including such regions on a $\beta$-globin construct. If such sequences are insensitive to position effects, we would expect, first, that the level of expression of the construct is directly related to its copy number in the transgenic mice; second, that the level of expression per gene copy is the same in each mouse; and third, that the introduced gene may be expressed at a level comparable to that of the mouse genes. Prior to testing the $5^{\prime}$ and 3 ' sequences, we wanted to map the positions of the hypersensitive sites carefully since their exact positions, especially at the $3^{\prime}$ side, have not been published in detail (Tuan et al., 1985).

\section{Mapping DNAase I-Hypersensitive Sites Flanking the $\beta$-Globin Locus}

Very limited DNAase I digestion of nuclei of erythroid cells reveals extremely sensitive sites upstream of the $\varepsilon$-globin 
A

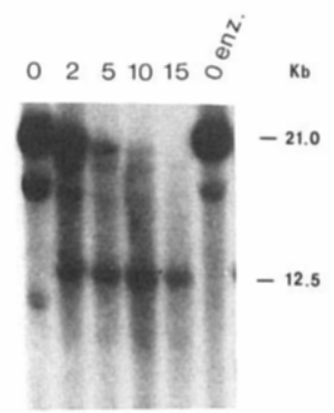

Recut: Asp 718

Probe: $\quad 1.15 \mathrm{Eco} \mathrm{RI}$
B

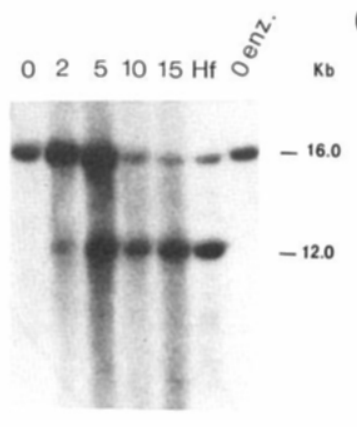

$\mathrm{Bam} \mathrm{HI}$
C

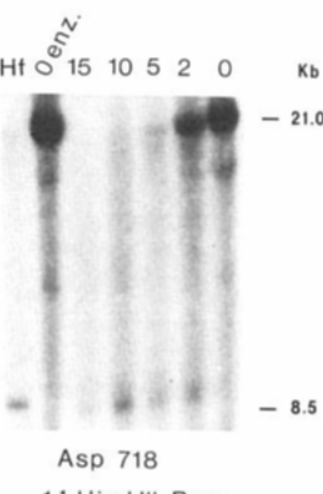

1.1 Hind III Bam
D

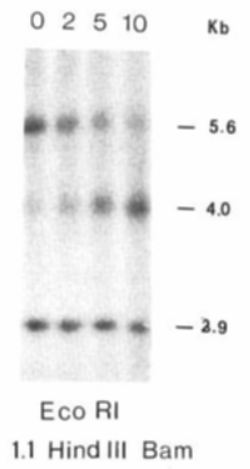

\section{E}

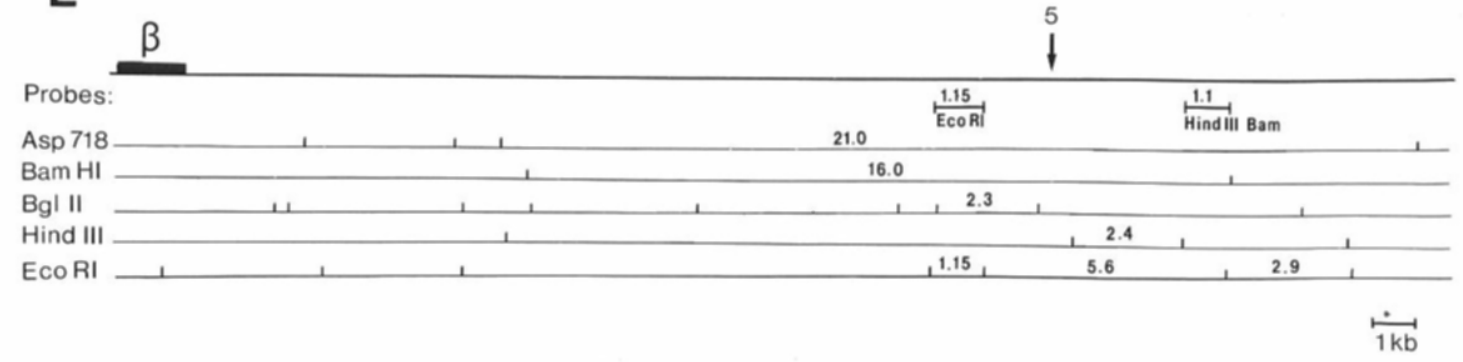

Figure 2. Mapping the DNAase 1-Hypersensitive Site $3^{\prime}$ of the Human $\beta$-Globin Gene

(A-D) show DNA from DNAase I-digested nuclei of HEL cells recut with the indicated restriction enzymes and probed with either a $1.15 \mathrm{~kb}$ EcoRI fragment or a $1.1 \mathrm{~kb}$ HindlII-BamHI fragment; abbreviations are as in Figure 1. Both DNA probes contain some human repetitive DNA, which necessitated the use of $10 \mu \mathrm{g}$ sheared human DNA per $\mathrm{ml}$ in prehybridization and hybridization buffers. Filters were washed at a final stringency of $0.3 \times$ $\mathrm{SSC}$ at $65^{\circ} \mathrm{C}$. (E) shows a restriction map of the $\beta$-globin locus $3^{\prime}$ of the $\beta$-globin gene; the positions of the two probes used and the $3^{\prime}$ hypersensitive site are marked. The position of hypersensitive site 5 was confirmed by probing Hindlll- and Bglll-recut DNA samples with the $1.15 \mathrm{~kb}$ EcoRI probe (not shown).

gene and downstream of the $\beta$-globin gene (Tuan et al., 1985). We fine-mapped the DNAase I-hypersensitive sites relative to restriction sites mapped in our cosmids (Taramelli et al., 1986). Figures 1A-1C show time courses of DNAase I digestion on nuclei of HEL (Martin and Papayannopoulou, 1982) and PUTKO (Klein et al., 1980) cells recut with various restriction enzymes, Southern blotted, and hybridized with a number of probes upstream of the $\mathrm{c}$-globin gene (see Figure 1E). Four hypersensitive sites are present, at $18 \mathrm{~kb}$ (site 1), $15 \mathrm{~kb}$ (site 2), 12.0 and $11.5 \mathrm{~kb}$ (sites $3 \mathrm{a}$ and $3 \mathrm{~b}$ ), and $5.4 \mathrm{~kb}$ (site 4) upstream of the $\varepsilon$-globin gene. Sites $1,3 \mathrm{a}$, and 4 are strongly hypersensitive, as judged by their early appearance during the time course of digestion. Sites 2 and $3 \mathrm{~b}$ are weaker and appear later during digestion. Figure $1 \mathrm{D}$ shows DNAase I digestion of nuclei of human T cell line $\mathrm{J} 6$ (Gillis and Watson, 1981). DNAase I-hypersensitive sites $5^{\prime}$ of $\varepsilon$ are not seen. Similar results were obtained with HeLa cell nuclei, showing the erythroid-specific nature of these hypersensitive sites.

The exact location of the DNAase I-hypersensitive site $3^{\prime}$ of the adult $\beta$-globin gene was determined using two single-copy DNA probes and several restriction enzyme digests of DNAase I-digested HEL cell nuclei. The data summarized in Figures $2 A-2 D$ show that there is a single DNAase I-hypersensitive site between the $2.3 \mathrm{~kb}$ Bglll fragment and the $2.4 \mathrm{~kb}$ HindllI fragment approximately $20 \mathrm{~kb} 3^{\prime}$ of the adult $\beta$-globin gene (Figure 2E). Similar results were obtained with DNAase I-digested PUTKO cell nuclei (data not shown).

\section{Construction of the $\beta$-Globin "Minilocus"}

The globin "minilocus" (Figure 3 ) was constructed from three regions (see Experimental Procedures for the precise description): a $21 \mathrm{~kb}$ region immediately upstream of the $\varepsilon$-globin gene $(-1 \mathrm{~kb}$ Clal to $-22 \mathrm{~kb}$ Bglll) containing all four hypersensitive sites (Figure 1), a $4.7 \mathrm{~kb}$ Bglll fragment containing the $\beta$-globin gene and all the known regulatory sequences immediately in and around the gene, and a $12 \mathrm{~kb}$ region downstream of the $\beta$-globin gene $(+12 \mathrm{~kb} \mathrm{Kpnl}$ to $+24 \mathrm{~kb} \mathrm{BamHI})$ containing the downstream hypersensitive site (Figure 2). These regions contained or were provided with unique linkers to create a series of unique restriction sites (Sall, Xhol, Clal, Kpnl, and Pvul) and were cloned into the cosmid pTCF (Grosveld et al., 1982). The entire $38 \mathrm{~kb}$ insert was excised from the 


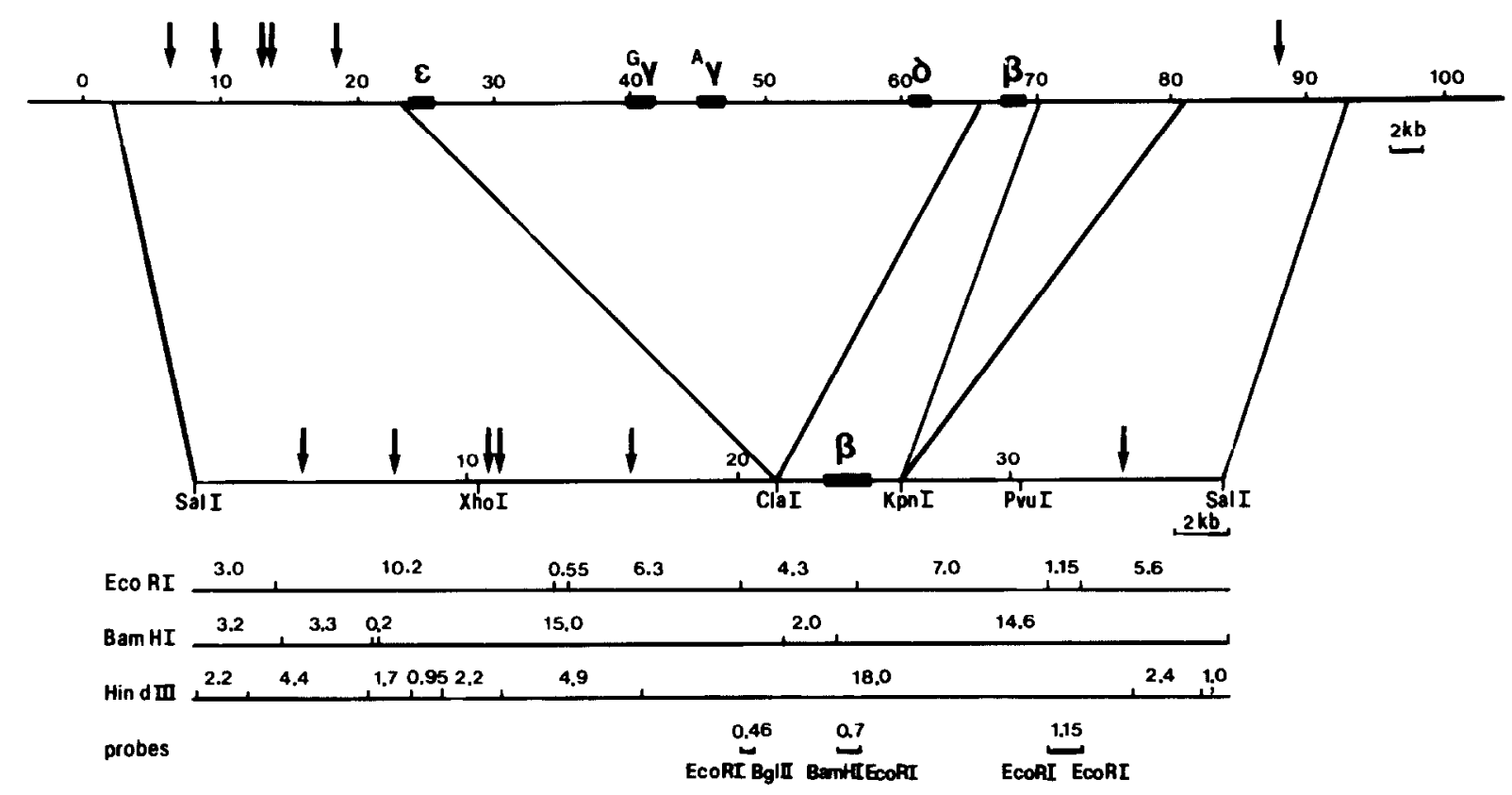

Figure 3. Construction of the Human B-Globin Minilocus

The human $\beta$-globin locus is illustrated at the top; sizes are shown in $\mathrm{kb}$. The second line shows the $\beta$-globin minilocus, containing a number of unique restriction sites; the connecting lines indicate the original positions of the fragments in the $\beta$-globin locus. The sizes of the EcoRI, BamHI, and HindlII restriction fragments in the minilocus are shown below in $\mathrm{kb}$. The hybridization probes for the $5^{\prime}$ flanking region (EcoRI-Bgll! $0.46 \mathrm{~kb}$ ), the $\beta$-globin gene (BamHI-EcoRl $0.7 \mathrm{~kb}$, IVS II), and the $3^{\prime}$ flanking region (EcoRl $1.15 \mathrm{~kb}$ ) are shown at the bottom.

cosmid as a Sall fragment, purified from low-melting-point agarose, and injected into fertilized mouse eggs (Kollias et al., 1986).

\section{Transgenic Mice Containing the $\beta$-Globin Minilocus} Initial injection of mouse eggs was carried out with a DNA concentration of $2 \mu \mathrm{g} / \mathrm{ml}$; the eggs were transplanted back into mice, but no offspring were obtained (for unknown reasons). Several series of injections were then carried out with a DNA concentration of $0.5-1 \mu \mathrm{g} / \mathrm{ml}$, and fetuses were collected after either 12.5 or 13.5 days of gestation. DNA was prepared from individual placentas, Southern blotted, and hybridized with a human $\beta$-globin probe to determine the number of transgenic mice, as described previously (Kollias et al., 1986). The transgenic DNAs were subsequently digested with EcoRI, Southern blotted, and hybridized with a human $\beta$-globin probe and a mouse Thy1 probe (single-copy) to determine the number of genes integrated in each mouse (Figure $4 A$ and Table 1). These values varied from a single insert (mice 33 and 38 ) to over one hundred copies per cell (mouse 21).

We then determined whether the inserted DNA was integrated intact or whether deletions and/or rearrangements had taken place after injection. Total DNA was digested with BamHI or HindIII, Southern blotted, and probed for the presence of the complete construct. In particular, a $0.46 \mathrm{~kb}$ Bglll probe (Figure 3) was used to detect the $15 \mathrm{~kb} \mathrm{BamHI}$ fragment at the $5^{\prime}$ end of the construct (Figure 4B), and a $1.15 \mathrm{~kb}$ EcoRI probe (Figure 3) was used to detect the $14.6 \mathrm{~kb} \mathrm{BamHI}$ or $18 \mathrm{~kb}$ Hindlll fragment

\begin{tabular}{lccc}
\hline \multicolumn{4}{l}{ Table 1. Levels of Human $\beta$-Globin RNA and DNA in Transgenic Mice } \\
\hline Mouse No. & $\beta / a$ RNA & $\beta /$ Thy-1 DNA & ANA/DNA \\
\hline 12 & 1.0 & 1.0 & 1.0 \\
17 & $42.0^{\mathrm{b}}$ & $47.2^{\mathrm{b}}$ & 0.9 \\
21 & N.D. $^{\mathrm{c}}$ & $>100$ & N.D. \\
24 & 0.3 & Chimera $^{\mathrm{d}}$ & N.D. \\
27 & 10.2 & 11.8 & 0.85 \\
33 & 0.5 & 0.5 & 1.0 \\
36 & 10.1 & 8.7 & 1.15 \\
38 & 0.1 & 0.4 & $<0.25$ \\
40 & 7.9 & 7.2 & 1.1 \\
Hu11 cell line & 0.3 & 0.5 & 0.6 \\
\hline
\end{tabular}

All values were normalized to mouse 12 as 1.0 (e.g., see Figures $4 \mathrm{~A}$ and $6 \mathrm{C}$ ) after densitometric scanning of autoradiographs exposed for different times from several experiments.

a The ratios were obtained by dividing the human $\beta$-globin RNA and DNA signals by those obtained for mouse $\alpha$-globin RNA and Thy- 1 DNA, respectively. Mouse 34 RNA was measured in only one experiment and not included.

b The DNA of mouse 17 was partially degraded (see Figure 4). We therefore used a low molecular weight cross-hybridizing band on the Thy-1 blot to quantitate the copy number (rather than the degraded $8 \mathrm{~kb}$ EcoRI Thy-1 band).

c The ratio of human $\beta$-globin to mouse $\alpha$-globin RNA was not determined (N.D.) accurately in this mouse because of the very high human to-mouse RNA signals (see text).

d Mouse 24 is mosaic for the human $\beta$-globin gene (Figure 6) and could therefore not be quantitated.

at the $3^{\prime}$ end of the construct (Figure 4C). All but two of the trangenic mice appeared to have intact $\beta$-globin miniloci, which are integrated in tandem arrays (not shown) as 

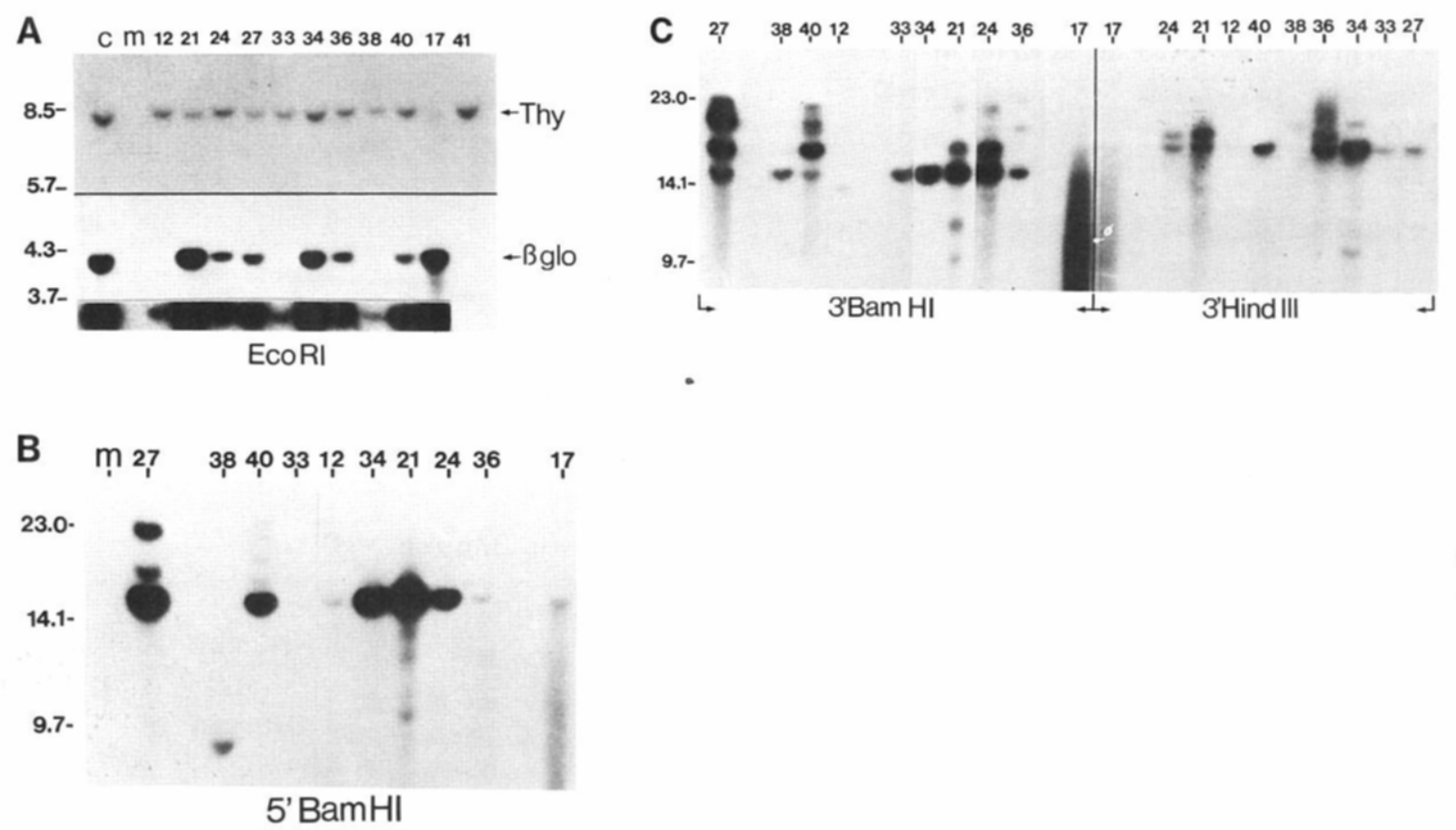

Figure 4. Structural Analysis of the Human $\beta$-Globin Transgene

(A) Approximately $5 \mu \mathrm{g}$ of placental or yolk sac DNA was digested with EcoRI, Southern blotted after gel electrophoresis, and hybridized to either the human $\beta$-globin BamHI-EcoRI IVS II probe (see Figure 3) or a mouse Thy-1 probe. The gels were quantitated by densitometric scanning of different exposures. The DNA of mouse 17 was partially degraded, and therefore a lower molecular weight Thy-1 cross-hybridizing band was used to quantitate this sample. The inset at the bottom of the figure is a long exposure $(10 \mathrm{x})$ of the globin hybridization to show the low copy signals.

(B) Placental or yolk sac DNA was digested with BamHI, Southern blotted, and hybridized to a 5 ' flanking probe (EcoRI-BamHI $0.46 \mathrm{~kb}$; Figure 3 ).

(C) Placental or yolk sac DNA was digested with BamHI or Hindill, Southern blotted, and hybridized to a $3^{\prime}$ flanking probe (EcoRI 1.15 kb; Figure 3).

In all panels samples contained mixed-in marker DNA ( $\lambda$ DNA digested with BstEll or Hindlil). The transgenic mice are numbered above the lanes; empty lanes contain DNA samples from nontransgenic mice. Sizes are in $\mathrm{kb}$. Some of the DNA samples are partially digested, although the mixed-in $\lambda$ DNA control was completely digested (not shown). This results in bands that are larger than the $14.6 \mathrm{~kb}$ Bam HI fragment (14.6 kb $+3.2 \mathrm{~kb}+$ $3.3 \mathrm{~kb})$ or the $18 \mathrm{~kb}$ Hindlil fragment $(18 \mathrm{~kb}+2.4 \mathrm{~kb}+3.4 \mathrm{~kb})$ because of cleavage at the next BamHI or Hindlll site in the tandem arrays.

judged by the presence of the correctly sized fragments. It should be noted, however, that the BamHI and HindllI sites at the $3^{\prime}$ end of the locus (Figures 4 and 6) are very resistant to cleavage, even though the mixed-in control $\lambda$ DNA has been fully digested (see Experimental Procedures). This results in partial-cleavage bands that are larger than the fully digested BamHI (14.6 kb) and HindIII $(18 \mathrm{~kb})$ fragments. Transgenic mouse 38 has not retained a full copy of the $\beta$-globin minilocus. The single copy present in this mouse has lost the BamHI and HindIII sites upstream of the $\beta$-globin gene, although the EcoRI site is still present. This indicates that all the $5^{\prime}$ flanking DNA, including the whole hypersensitive site region, has been deleted in this mouse. Mouse 12 has suffered a small $(<1 \mathrm{~kb})$ deletion of sequences at the $3^{\prime}$ end of the insert, but this does not inciude the $3^{\prime}$ hypersensitive site.

\section{The Human $\beta$-Globin Minilocus Is Fully Active}

To measure the activity of the human $\beta$-globin gene, RNA was prepared from all the transgenic and nontransgenic fetuses (liver, blood, and brain) and analyzed by $S 1$ nuclease protection analysis. Figure $5 \mathrm{~A}$ shows the analysis of liver RNA using a $5^{\prime}$ human $\beta$-globin probe, while
Figure 5B shows an analysis of the $3^{\prime}$ end of the human $\beta$-globin RNA in the presence of a mouse $\alpha$-globin probe as an internal control. These results show that the human $\beta$-globin transcript is correctly initiated and polyadenylated and that the levels of RNA are proportional to the number of copies of the minilocus in each mouse (except mice 24 and 38; see below). Nonerythroid tissue does not show any human $\beta$-globin mRNA except when it is contaminated with blood during isolation. In such cases, low levels of both human and mouse $\beta$-globin RNA are found with the same ratio as in erythroid tissue. The level of expression is clearly very high when the ratio of the human $\beta$-globin to mouse $\beta$-globin RNA levels (Table 1 ) is compared to that of the Hu11 cell control (Zavodny et al., 1983); the latter cell line is an MEL cell line containing the human $\beta$-globin locus on a human $X-11$ hybrid chromosome.

To carefully quantitate the levels of expression in these mice, we analyzed the RNA levels in mice 33 and 12 , which have one and two intact copies of the $\beta$-globin locus, and in the two exceptions, mice 24 and 38 , using mouse and human $\beta$-globin probes of equal specific activity. Figure $5 \mathrm{C}$ shows that the signal of the human $\beta$-globin gene is approximately half that of the mouse $\beta$-globin 
A
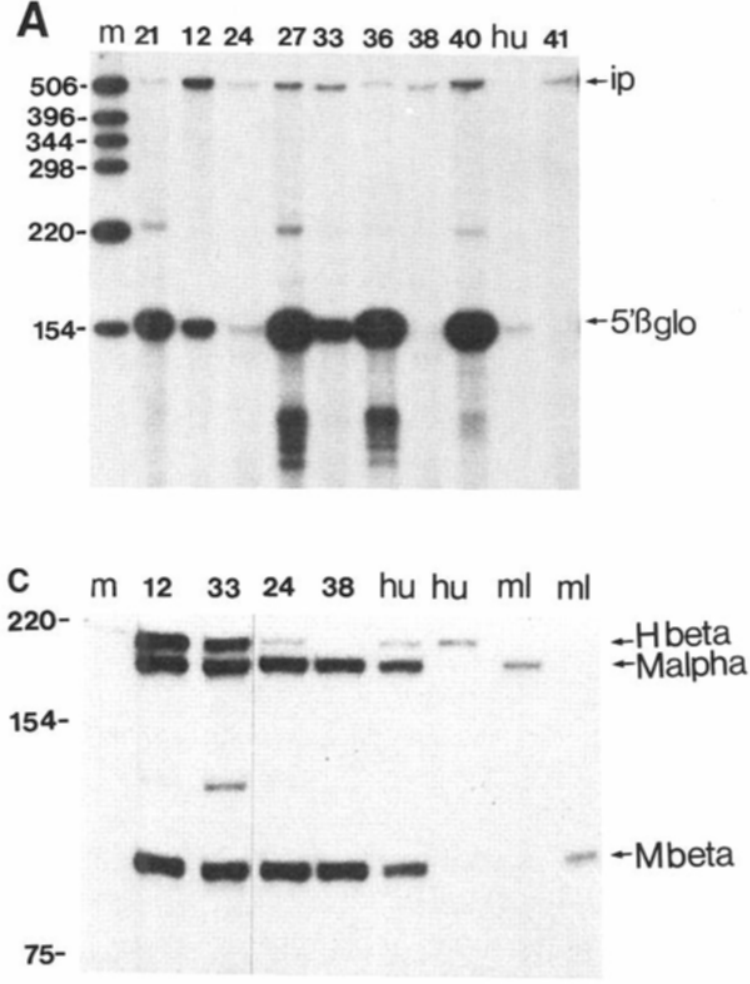

B
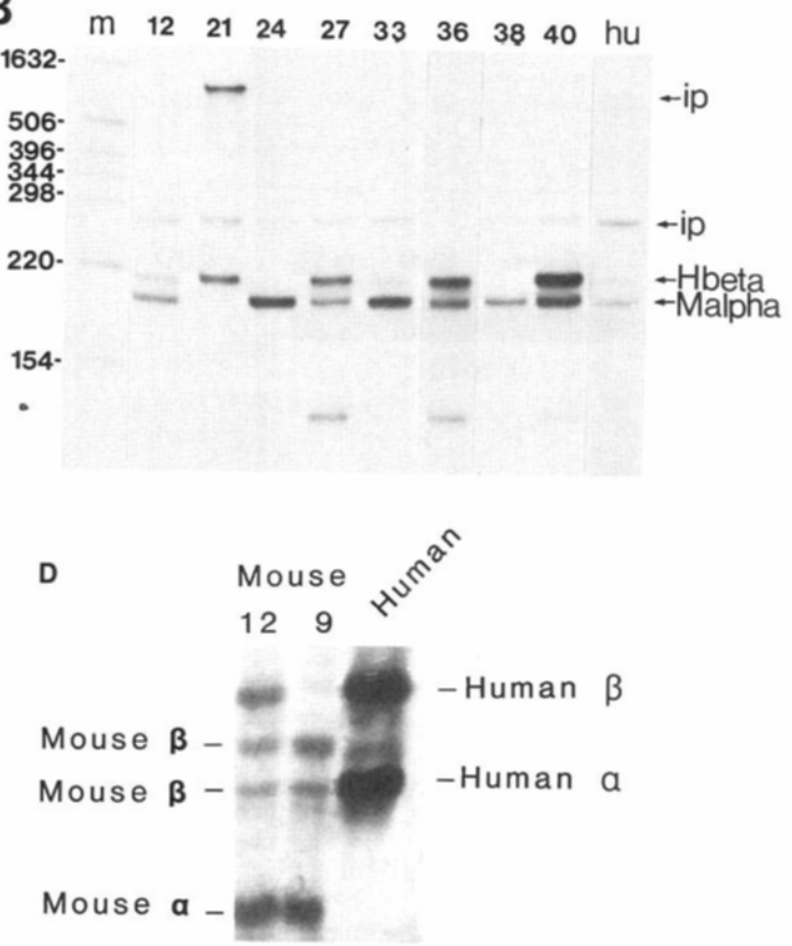

Figure 5. Expression Analysis of the Human $\beta$-Globin Transgene

(A) Five microgram aliquots of RNA from 12.5 or 13.5 day livers from different mice (numbers above lanes) were analyzed by $S 1$ nuclease protection as described previously (Kollias et al., 1986). The protected fragment of the $5^{\prime}$ human $\beta$-globin probe (525 bp Accl fragment from an IVS I-lacking $\beta$-globin gene) is 160 nucleotides long. ( $5^{\prime} \mathrm{Bglo}$ ). The input probe is shown as ip. The marker lane (m) contains pBR322 DNA digested with Hinfl; sizes are indicated in nucleotides. The positive control is RNA from the hybrid MEL cell line Hu11 (lane hu).

(B) Five microgram aliquots of RNA were analyzed as in (A), but using two probes: a $3^{\prime}$ probe of the human $\beta$-globin gene (760 bp EcoRI-Mspl fragment), resulting in a 210 nucleotide protected fragment ( $H$ beta); and a mouse $\alpha$-globin probe (260 bp BamHI second exon probe), resulting in a 170 nucleotide protected fragment ( $M$ alpha). Other designations are as in (A).

(C) Five microgram aliquots of RNA were analyzed as in (B), but in addition a mouse 3 maj-globin probe (a 730 bp second exon probe) was added, resulting in a 100 nucleotide protected fragment ( $M$ beta). The probes were of equal specific activity. The activity of the probes was assessed by quantitative agarose gel electrophoresis and autoradiography of the individual probes before and after mixing for the $\mathrm{S} 1$ nuclease analysis (not shown). Each probe was individually tested with Hu11 RNA (hu) or nontransgenic mouse fetal liver RNa (ml).

(D) Samples of fetal liver (approximately $20 \mu \mathrm{g}$ ) or human red cells were lysed in $\mathbf{4 0} \mu \mathrm{l}$ of $\mathrm{H}_{2} \mathrm{O}$ and the globin proteins were separated, as described by Alter et al. (1980). The gel was stained to visualize the globin protein chains. Mouse 9 is an age-matched, nontransgenic littermate of mouse 12. The positions of mouse $\alpha-$ and $\beta$-globin and human $\beta$-globin are indicated.

diploid in mouse 33 , but the signals are equal in mouse 12. This is confirmed at the protein level, when the red cells of mouse 12 and an age-matched control are lysed and the proteins run on a Triton-acid-urea gel (Alter et al., 1980). It is clear that transgenic mouse 12 expresses equal levels of mouse and human $\beta$-globin proteins (Figure 5D). From all these data we conclude that each human $\beta$-globin gene in these mice is fully active, i.e., is expressed at a level equivalent to that of the mouse $\beta$-globin genes, while the expression in mice 24 and 38 is suppressed. A peculiar situation is found in mice 21 and 17. The mouse $\beta$-globin RNA levels are very low in these mice, presumably as a result of the very high copy number of the human $\beta$-globin gene and, as a consequence, the very high mRNA (and protein) levels. The high copy number possibly results in a competition for transcription factors (mouse $\beta$-globin RNA is decreased more than mouse $\alpha$-globin RNA; Figure $5 B$ ), while the high levels of $\beta$-globin protein definitely result in an anemia ( $\alpha$-thalassemia) Mice 21 and 17 had small, colorless livers, consistent with the destruction of mature red cells and concomitant loss of mRNA.

Two mice ( 38 and 24) are exceptions because they express relatively lower amounts of human $\beta$-globin (Figures $5 A-5 C$; Table 1). The situation in mouse 38 is explained by the fact that this is the only transgenic mouse in which the $5^{\prime}$ end of the locus is deleted (Figure 4). As a consequence, the human $\beta$-globin gene is still expressed, but in a position-dependent manner and at low levels, just as when small $\beta$-globin fragments are introduced in mice (Kollias et al., 1986; Magram et al., 1985; Townes et al., 1985). Mouse 24 has no apparent defect in the locus, and we investigated the possibility that this mouse is a true exception or whether it is a mosaic mouse or has the $\beta$-globin locus integrated on an inactive $X$-chromosome. We therefore isolated DNA from the yolk sac, brain, and fetal 


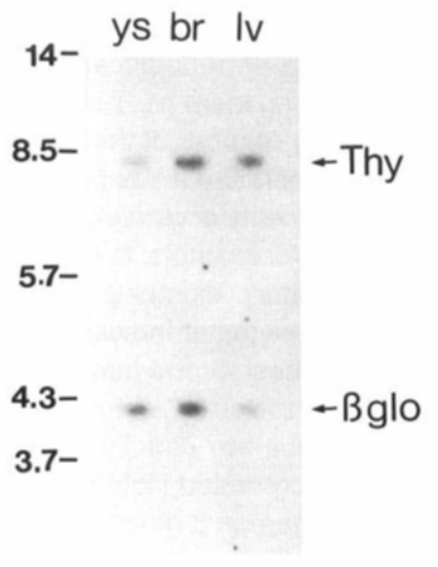

Figure 6. Mouse 24 Is Chimeric for the Human $\beta$-Globin Gene

Five micrograms of yolk sac (ys) DNA and $10 \mu \mathrm{g}$ of fetal liver (Iv) and brain (br) DNA were digested with EcoRI, Southern blotted, and hybridized as described in Figure 4A. liver (the "erythroid" tissue) and hybridized the EcoRIdigested DNAs on Southern blots with a human $\beta$-globin probe and a murine Thy- 1 probe, to detect the $\beta$-globin transgene versus an endogenous single-copy gene. Figure 6 clearly shows that $10 \mu \mathrm{g}$ of the fetal liver DNA contains even less than half of the globin signal than $5 \mu \mathrm{g}$ of yolk sac DNA; i.e., fewer than $25 \%$ of the liver cells contain the $\beta$-globin gene. This is therefore a mosaic mouse in which the $\beta$-globin minilocus is underrepresented in the erythroid tissue (fetal liver), which explains the lower levels of human $\beta$-globin mRNA found in these cells. We conclude that provided the locus has not been affected, there is a complete correlation between expression levels and DNA copy numbers and that each gene is fully expressed in every transgenic mouse.

\section{Mapping DNAase I-Hypersensitive Sites} in the Transgenic $\beta$-Globin Locus

The DNAase 1-hypersensitive sites flanking the $\beta$-globin locus are found in all erythroid tissues studied, regardless

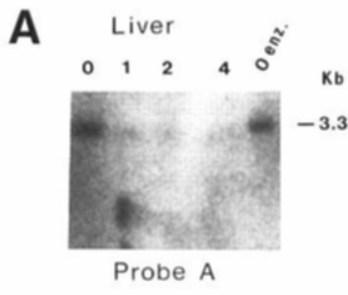

B

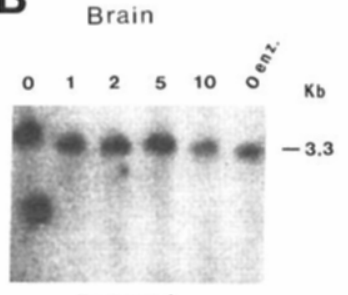

Probe A

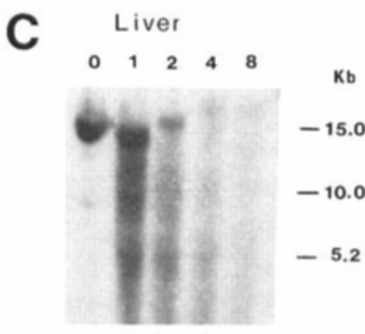

Probe B

D

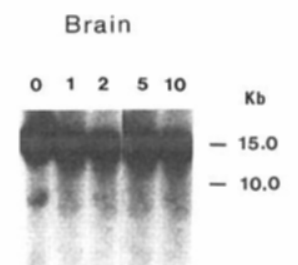

$-5.2$
E

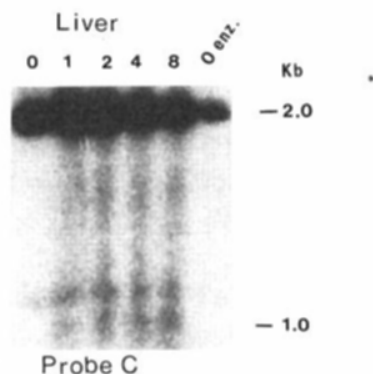

F

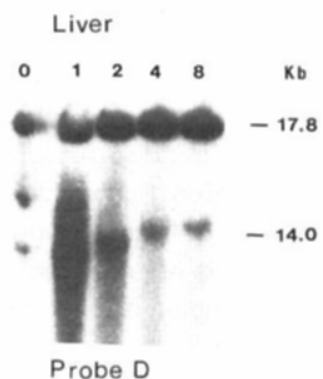

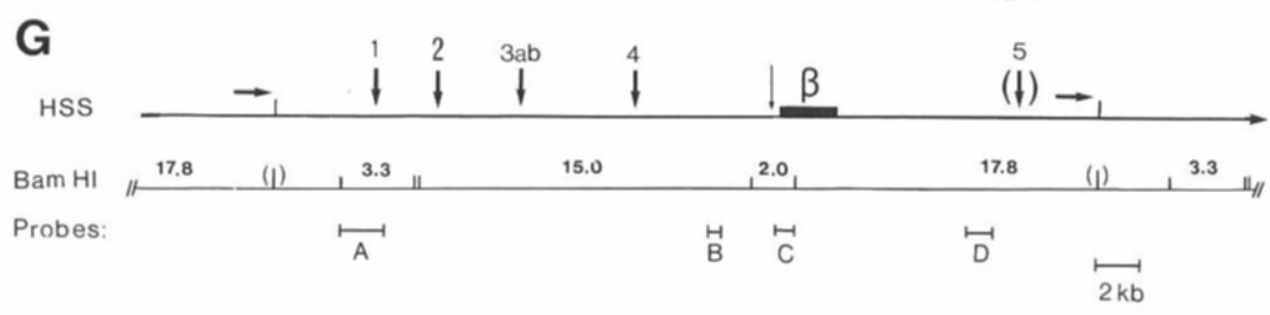

Figure 7. DNAase 1-Hypersensitive Sites Are Reformed on the Transgenic $\beta$-Globin Minilocus

(A-F) Nuclei of mouse 21 tissues were incubated at $37^{\circ} \mathrm{C}$ with DNAase I at $5 \mu \mathrm{g} / \mathrm{ml}$ for $0,1,2,4$, or 8 min (liver), or $0,1,2,5$, or $10 \mathrm{~min}$ (brain). Control aliquols of nuclei were incubated for 8 or $10 \mathrm{~min}$ in the absence of DNAase I (lanes 0 enz.). Purlfied DNA was recut with BamHI, fractionated on a $0.6 \%$ agarose gel, transferred to nitrocellulose, and probed with DNA fragments spanning the transgenic human $\beta$-globin minilocus. The 14.0 $\mathrm{kb}$ BamHl fragment detected by probe $D$ in $(F)$ is a junction fragment of the tandem array of the $\beta$-globin minilocus. The $17.8 \mathrm{~kb}$ band is the result of incomplete BamHI digestion. (G) is a schematic representation of a repeat unit of the minilocus tandem array in mouse 21; DNAase I-hypersensitive sites are marked. Site 5 is not reformed in fetal liver nuclei (F). DNAase I subbands corresponding to hypersensitive sites 1 and 2 are not seen in DNAase I fade-out experiments, but the BamHI fragments in which they reside are sensitive to DNAase I digestion in liver (A and C) but not brain (B and D). 
of which $\beta$-like globin is expressed. To determine if the DNAase I-hypersensitive sites are reformed in the $\beta$-globin minilocus of transgenic mice expressing high levels of human $\beta$-globin mRNA, a DNAase I "fade-out" was performed on small samples of liver and brain nuclei of mouse 21 (which has the highest copy number of the $\beta$ gene minilocus) (Figure 7). Limited DNAase I digestion was carried out in the presence of carrier fetal liver or brain nuclei; purified nuclear DNA was recut with BamHI, fractionated, and Southern blotted, and fragments spanning the whole construct were used as hybridization probes. The $1.15 \mathrm{~kb}$ EcoRl probe used to detect the $3^{\prime}$ hypersensitive site in HEL and PUTKO cells detects a 17.8 kb BamHI fragment, which is due to partial digestion of the BamHI site at the $3^{\prime}$ end of the injected fragment. The $17.8 \mathrm{~kb} \mathrm{BamHI}$ fragment is completely insensitive to limited DNAase I digestion in liver nuclei of mouse 21 (Figure 7F). The same filter reprobed with a $600 \mathrm{bp} \mathrm{Accl} 5^{\prime}$ human $\beta$-globin probe shows that the $2.0 \mathrm{~kb} B a m H I$ fragment encompassing the $5^{\prime}$ end (to $-1460 \mathrm{bp}$ ) of the highly transcribed human $\beta$-globin gene is slightly sensitive to DNAase I digestion, revealing a DNAase I subband of approximately $1 \mathrm{~kb}$ (Figure 7E), consistent with a DNAase I-hypersensitive site within the $\beta$-globin gene promoter (Groudine et al., 1983). Reprobing the same filter with the $0.46 \mathrm{~kb}$ EcoRl-Bglll probe (Figure 1c) shows that the 15 $\mathrm{kb}$ BamHI fragment encompassing hypersensitive sites 2, $3 a, 3 b$, and 4 is exceedingly sensitive to DNAase I digestion in fetal liver nuclei; subbands corresponding to cutting at sites 3 and 4 are clearly visible. The same $15 \mathrm{~kb}$ BamHI fragment of the $\beta$ transgene minilocus is insensitive to DNAase I digestion in brain nuclei of the same animal (Figure 7D). The $3.3 \mathrm{~kb}$ BamHI fragment (containing hypersensitive site 1) of the transgenic minilocus is also very sensitive to DNAase I digestion in liver, but not brain nuclei of mouse 21 (Figures 7A and 7B). In summary, the $5^{\prime}$ flanking region is extremely sensitive to DNAase I digestion and has retained the superhypersensitive sites in a tissue-specific fashion. Surprisingly, the $3^{\prime}$ flanking region is insensitive to DNAase I digestion, and the superhypersensitive site is not retained. The normal hypersensitivity in the promoter is present (Groudine et al., 1983).

\section{Discussion}

\section{Position-Effect-Independent Expression}

The introduction of the human $\beta$-globin gene flanked by the upstream and downstream regions in transgenic mice has resulted in an expression pattern that is positionindependent and directly related to copy number, with levels of human $\beta$-globin mRNA as high as mouse $\beta$-globin mRNA. This is different from results observed previously with transgenic mice created using the $\beta$-globin gene alone (Magram et al., 1985; Chada et al., 1985; Townes et al., 1985; Kollias et al., 1986, 1987) or other genes such as the immunoglobulin genes (Grosschedl et al., 1984), albumin genes (Pinkert et al., 1987), the Thy-1 gene (Kollias et al., 1987), the $\alpha$-fetoprotein gene (Hammer et al., $1987)$, and many others. As a result of position effects in all transgenic mice experiments to date, the level of transgenic expression has been suboptimal and has varied between different mice; i.e., there has been no strict correlation between the copy number of the transgene and the level of expression. Therefore it has been very difficult to quantitate any experiments accurately, and as a result, it has been impossible, for example, to examine the cooperation between regulatory elements in any gene. The results described in this paper indicate that this problem can be overcome, at least for the human $\beta$-globin genes. It is clear that the expression levels found in mice containing the intact minilocus are directly proportional to the number of genes incorporated (Table 1). In addition, the expression level per human $\beta$-globin gene in all of those mice is very similar to that observed for the endogenous mouse $\beta$-globin gene (Figure 5 ). We therefore conclude that the $\beta$-globin locus flanking sequences confer position-independent expression on the $\beta$-globin gene, which itself is expressed erythroid-specifically. In addition, we conclude that all of the regulatory sequences involved in $\beta$-globin gene expression are included in this construct.

\section{The Requirement for and Function of the Flanking Regions}

It is not clear from these data what minimal sequences in the flanking regions are required for the complete and independent expression of the gene. Certainly, the $5^{\prime}$ flanking region is required. Deletion of the upstream region in vivo results in a $\beta^{0}$ thalassemia (Kioussis et al., 1983; Curtin and Kan, 1987), and deletion of this region in mouse 38 (Figure 4) results in reduced expression (Figure 5 ). In heterozygous Dutch $\gamma \beta$-thalassemia patients there are no secondary mutations in the affected gene; all the regulatory regions normally near or within the gene are present, and all the factors required to transcribe the gene are present in the nucleus, since the second (normal) allele is expressed with normal efficiency. The same argument is true for mouse 38, which expresses normal levels of mouse $\beta$-globin. This shows that this region exerts a dominant control on the expression of the $\beta$-globin locus. It is tempting to speculate from the DNAase I sensitivity data (Figure 7) that only the $5^{\prime}$ region, but not the $3^{\prime}$ region, is required, and that the actual active regions are the sequences at the hypersensitive sites. It should be pointed out, however, that the presence or absence of hypersensitive sites may not necessarily correlate with the control region of position-independent expression, and that the $3^{\prime}$ flanking region might also be important, although it is clear that the $3^{\prime}$ region alone is not sufficient (mouse 38 , Figure 4).

The control region(s) in the flanking DNA is completely dominant (see above), and the hypersensitive sites are erythroid-specific and present at all erythroid developmental stages (Figures 1, 2, and 7; Tuan et al., 1985). They are even dominant after fusion of a globin-expressing cell line (K562) to a nonerythroid cell line myeloma (Klein et al., 1980), resulting in a globin-expressing hybrid cell (PUTKO) (see Figures 1 and 2). It is likely that the regions control the accessibility of the $\beta$-globin locus to transacting factors, perhaps like the border regions flanking the 
DNAase I-sensitive domain originally described for the ovalbumin gene (Lawson et al., 1982). These borders may contain nuclear-matrix-binding sites, which have been poorly defined in mammalian cells but have been mapped in detail in Drosophila (Gasser and Laemmli, 1986). Alternatively, the globin locus flanking regions might contain one or several enhancer-like sequences, which can exert their effect over very large distances $(>50 \mathrm{~kb})$ and would be required to set up efficient transcription complexes. An attractive possibility is that such enhancers and matrixbinding sites are actually the same or neighboring sequences (Cockerhill and Garrard, 1986). It is likely that similar control regions will be present in other tightly controlled, tissue-specific gene systems. To date, all experiments with other genes in transgenic animals have been carried out with small fragments and have been subject to position effects. However, genes expressed at low levels and those expressed ubiquitously may be controlled differently.

It is not clear whether the sequences we describe here are specific for $\beta$-globin genes, or whether they might also be present in the $\alpha$-globin gene locus, providing coordinate regulation. A recently described $\alpha$-thalassemia shows a deletion in the $5^{\prime}$ flanking region of the locus similar to that described for the $\gamma \beta$-thalassemia (Nicholls et al., 1987). It is also not yet clear whether these sequences will exert a similar dominant effect on other genes. To answer this question, we are currently testing the expression of heterologous genes cloned into the $\beta$-globin minilocus construct.

\section{The Mechanism of $\beta$-Globin Gene Switching}

We have now identified at least five different control regions in the $\beta$-globin gene: the dominant control region described in this paper, positively negatively acting sequences in the promoter (Antoniou and Grosveld, submitted; Grosveld et al., 1987), and two enhancer sequences, one in the gene and one in the immediate $3^{\prime}$ flanking region (Kollias et al., 1987; Townes et al., 1987; Costantini et al., personal communication). On that basis, we propose the following model for the control of globin gene expression during development: The dominant control region determines the activity of the locus. In inactive, nonerythroid tissues there are no hypersensitive sites, and the DNA is not accessible to trans-acting factors. In erythroid cells the dominant control region becomes extremely hypersensitive (possibly not requiring replication) and renders the chromatin of the globin locus accessible to trans-acting factors. The proteins that mediate this action might be matrix-bound, such as topoisomerases to change the winding of the locus and/or enhancer-binding factors (Angel et al., 1987; Lee et al., 1987). This control defines the globin domain and provides position-independent expression. Action of the dominant control region then mediates the binding of trans-acting factors to regulatory promoter and enhancer sequences immediately surrounding the globin genes. This process determines the stage-specific expression-i.e., $\varepsilon$-globin gene expression in the embryonic yolk sac, $\gamma$-globin gene expression in the fetal liver, and $\beta$-globin gene expression in the adult. In the case of the $\beta$-globin gene, this process would involve a negative factor and regulatory sequence to suppress the gene at the embryonic and fetal stages, and positive factors acting on the enhancers and the promoters to set up a very active transcription complex.

\section{Gene Therapy}

Perhaps the most interesting application for the dominant control region(s) is that it might allow completely regulated expression of the $\beta$-globin gene (and possibly other genes) in retroviral vector or transfection systems. Gene expression in such systems is at present position-dependent and inefficient. In particular, retroviral vector systems, which are currently the only efficient means of transferring genes into hematopoietic (or other) stem cells, are very sensitive to the integration site of the retroviral vector (Cone et al., 1987). Inclusion of the globin dominant control regions may solve this problem and allow the efficient transfer of a fully active, single-copy human globin gene to hematopoietic stem cells. This would form the basis for gene therapy by gene addition in the case of thalassemias.

\section{Experimental Procedures}

\section{Transgenic Mice}

The $38 \mathrm{~kb}$ Sall fragment was purified from cosmid vector sequences by gel electrophoresis and prepared for injection as previously described (Kollias et al., 1986; Brinster et al., 1985). Transgenic fetuses were identified by Southern blot analysis (Southern, 1975) of placental DNA

\section{RNA Analysis}

RNA extraction of different tissues and $S 1$ nuclease protection analysis were carried out as described previously (Kollias et al., 1986).

\section{DNAase Sensitivity}

DNAase I sensitivity assays were carried out on isolated nuclei as de scribed by Enver et al. (1985), except that $1 \mathrm{mM}$ EGTA was included in all buffers until DNAase I digestion in buffer $A$ plus $1 \mathrm{mM} \mathrm{CaCl}$ was performed. In the case of transgenic liver and brain, four livers and brains from age-matched normal fetuses were added as carriers to provide sufficient material to carry out the analysis.

\section{Construction of the $\beta$-Globin Minilocus}

-A $12 \mathrm{~kb}$ Bglll fragment (10-22 kb $5^{\prime}$ of the $\beta$-globin gene) was cloned into the BamHI site of cosmid pTCF (Grosveld et al., 1982) without a Clal site, forming cos $\mathrm{HGB12}$

- cos HGB12 was cleaved with Asp718 (13.5 kb 5' of the $\varepsilon$-globin gene), and a unique Xhol linker was inserted, forming cos HGB12X - cos HG14.2 (Taramelli et al., 1986), containing the entire $\varepsilon$-globin upstream region, was cleaved with $\mathrm{Kpnl}$, and an Xhol linker was inserted and packaged, forming cos HG14.2X.

-A Clal linker was inserted in the Xbal site of pUC18, to form pUC18C -The $4.7 \mathrm{~kb}$ Bglll fragment containing the $\beta$-globin gene was inserted in the BamHI site of pUC18C, yielding PUC18C-BG

$-A 12 \mathrm{~kb} \mathrm{Hpal-BamHI}$ fragment (12-24 kb $3^{\prime}$ of the $\beta$-globin gene) was cloned into the Hpal-BamHI site of cosmid pTCF lacking a Cla site, forming cos HGHB12.

-The final cosmid construct was formed by the ligation and packaging of four fragments: a $16.5 \mathrm{~kb}$ Pvul-Xhol fragment from cos HGB12X containing the cosmid and part of the upstream sequences, an $11 \mathrm{~kb}$ Xhol-Clal fragment from cos HG14.2X containing the remainder of the upstream sequences, a $4.7 \mathrm{~kb}$ Clal-Kpnl fragment from pUC18C-BG containing the $\beta$-globin gene, and a $19 \mathrm{~kb} \mathrm{Kpnl-Hpal} \mathrm{fragment} \mathrm{from}$ cos HGHB12 containing the $3^{\prime}$ flanking region and the second cosmid for packaging purposes. The final construct was the cos $\mathrm{HG}$ minilocus (Figure 3). 


\section{Acknowledgments}

We are grateful to Ernie deBoer for helpful ideas and technical assistance, to Colin Hetherington and his staff for the supply and maintenance of animals, and to Cora O'Carroll for the preparation of the manuscript. G. K. was supported by a long-term EMBO Fellowship. G. B. was self-supported after initial support by a Ramsay Memorial Fellowship. This work was supported by the British Medical Research Council.

The costs of publication of this article were defrayed in part by the payment of page charges. This article must therefore be hereby marked "advertisement" in accordance with 18 U.S.C. Section 1734 solely to indicate this fact.

Received August 10, 1987; revised September 21, 1987.

\section{References}

Alter, B., Goff, S., Efremor, G., Gravley, M., and Huisman, T. (1980). Globin chain electrophoresis: a new approach to the determination of the $G_{\gamma} / A_{\gamma}$ ratio in foetal haemoglobin and to the studies of globin synthesis. Br. J. Haematol. 44, 527-534.

Angel, P., Imagawa, M., Chin, R., Stein, B., Imbra, R., Rahmsdorf, M., Jonat, A., Herrlich, P., and Karin, M. (1987). Phorbol ester-inducible genes contain a common cis element recognized by a TPA-modulated trans-acting factor. Cell 49, 729-739.

Behringer, R. R., Hammer, R. E., Brinster, R. L., Palmiter, R. D., and Townes, T. M. (1987). Two $3^{\prime}$ sequences direct erythroid-specific expression of human $\beta$-globin genes in transgenic mice. Proc. Natl. Acad. Sci. USA 84, 7056-7060.

Brinster, R. L., Chan, H. Y., Trumbauer, M. E., Yagle, M. K., and Palmiter, R. D. (1985). Factors affecting the efficiency of introducing foreign DNA into mice by microinjecting eggs. Proc. Natl. Acad. Sci. USA 82, 4438-4442.

Chada, K., Magram, J., Raphael, K., Radice, G., Lacy, E., and Costantini, F. (1985). Specific expression of a foreign $\beta$-globin gene in erythroid cells of transgenic mice. Nature 314, 377-380.

Charnay, P., Treisman, R., Mellon, P., Chao, M., Axel, R., and Maniatis, $T$. (1984). Differences in human $\alpha$ - and $\beta$-globin gene expression in mouse erythroleukemia cells: the role of intragenic sequences. Cell 38, 251-263.

Choi, O.-R., and Engel, J. D. (1986). A $3^{\prime}$ enhancer is required for temporal and tissue-specific transcriptional activation of the chicken adult $\beta$-globin gene. Nature $323,731-734$.

Cockerhill, P. N., and Garrard, W. T. (1986). Chromosomal loop anchorage of the kappa lg gene locus next to the enhancer in a region containing topoisomerase II sites. Cell 44, 273-282.

Collins, F. S., and Weissman, S. M. (1984). The molecular genetics of human hemoglobin. Prog. Nucl. Acid Res. Mol. Biol. 31, 315-462.

Cone, R. D., Benarous, W. W., Baorto, D., and Mulligan, R. C. (1987). Regulated expression of a complete human $\beta$-globin gene encoded by a transmissible retrovirus vector. Mol. Cell. Biol. 7, 887-897.

Curtin, P., and Kan, Y. W. (1987). A normal $\beta$-globin gene is inactivated by a large distant deletion. In Hemoglobin Switching, Fifth Conference on Hemoglobin Switching, G. Stamatoyannopoulos, ed. (New York: Alan R. Liss. Inc.) in press.

Enver, T., Brewer, A. C., and Patient, R. K. (1985). Simian virus 40-mediated cis induction of the Xenopus $\beta$-globin DNasel hypersensitive site. Nature 318, 680-683.

Forrester, W. C., Thompson, C., Elder, J. T., and Groudine, M. (1986) A developmentally stable chromatin structure in the human $\beta$-globin gene cluster. Proc. Natl. Acad. Sci. USA 83, 1359-1363.

Gasser, S. M., and Laemmli, U. K. (1986). Cohabitation of scaffold binding regions with upstream/enhancer elements of three developmen tally regulated genes of D. melanogaster. Cell 46, 521-530.

Gillis, S., and Watson, J. (1981). Interleukin-2 dependent culture of cytoIytic T cell lines. Immunol. Rev. 54, 81-109.

Grosschedl, R., Weaver, D., Baltimore, D., and Costantini, F. (1984). In troduction of a $\mu$ immunoglobulin gene into the mouse germ line: spe- cific expression in lymphoid cells and synthesis of functional antibody. Cell 38, 647-658.

Grosveld, F. G., Lund, T., Murray, E. J., Mellor, A. L., Dahl, H. H. M., and Flavell, R. A. (1982). The construction of cosmid libraries which can be used to transform eukaryotic cells. Nucl. Acids Res. 10, 6715-6732.

Grosveld, F. G., Antoniou, M., deBoer, E., Habets, G., Hurst, J., Kollias, G., MacFarlane, F., and Wrighton, N. (1987). The regulation of expression of human $\beta$-globin genes. In Molecular Approaches to Developmental Biology, R. A. Firtel and E. H. Davidson, eds. (New York: Alan R. Liss, Inc.), pp. 483-500.

Groudine, M., Kohwi-Shigematsu, T., Gelinas, R., Stamatayannopoulos, G., and Papayannopoulou, T. (1983). Human fetal to adult hemoglobin switching: changes in chromatin structure of the $\beta$-globin locus. Proc. Natl. Acad. Sci. USA 80, 7551-7555.

Hammer, R., Krumlauf, R., Campen, S., Brinster, R., and Tilghman, S. (1987). Diversity of $\alpha$-fetoprotein gene expression in mice is generated by a combination of separate enhancer elements. Science $235,53-58$. Hesse, J. E., Nickol, J. M., Lieber, M. R., and Felsenfeld, G. (1986). Regulated gene expression in transfected primary chicken erythrocytes. Proc. Natl. Acad. Sci. USA 83, 4312-4316.

Hock, R. A., and Miller, A. D. (1986). Retrovirus-mediated transfer and expression of drug resistance genes in human haematopoietic progenitor cells. Nature 320, 275-277.

Kioussis, D., Vanin, E., deLange, T., Flavell, R. A., and Grosveld, F. (1983). $\beta$-Globin gene inactivation by DNA translocation in $\gamma \beta$ thalassaemia. Nature 306, 662-666.

Klein, G., Zeuthen, J., Eriksson, I., Tekasaki, P., Bernoco, M., Rosen, A., Masucci, G., Povey, S., and Ber, R. (1980). Hybridization of a myeloid leukaemia derived human cell line (K562) with a Burkitt's lymphoma line. J. Natl. Cancer Inst. 64, 725-738.

Kollias, G., Wrighton, N., Hurst, J., and Grosveld, F. (1986). Regulated expression of human $A_{\gamma}$-, $\beta$-, and hybrid $\gamma \beta$-globin genes in transgenic mice: manipulation of the developmental expression patterns. Cell 46 , 89-94.

Kollias, G., Hurst, J., deBoer, E., and Grosveld, F. (1987). A tissue and developmental specific enhancer is located downstream from the human $\beta$-globin gene. Nucl. Acids Res. 15, 5739-5747.

Lawson, G., Knoll, B., March, C., Woo, S., Tsai, M., and O'Malley, B. (1982). Definition of $5^{\prime}$ and $3^{\prime}$ structural boundaries of the chromatin domain containing the ovalbumin multigene family. J. Biol. Chem. 257, 1501-1507.

Lee, W., Mitchell, P., and Tjian, R. (1987). Purified transcription factor AP-1 interacts with TPA-inducible enhancer elements. Cell 49, 741-752. Magram, J., Chada, K., and CostantinI, F. (1985). Developmental regulation of a cloned adult $\beta$-globin gene in transgenic mice. Nature 315 , 338-340.

Maniatis, T., Fritsch, E. F., Lauer, J., and Lawn, R. M. (1981). Molecular genetics of human hemoglobins. Ann. Rev. Genet. 14, 145-178.

Martin, P., and Papayannopoulou, T. (1982). HEL cells: a new human erythroleukemia cell line with spontaneous and induced globin expression. Science 216, 1233-1235.

Nicholls, R. D., Fischel-Ghodsian, N., and Higgs, D. R. (1987). Recombination at the human $\alpha$-globin gene cluster: sequence features and topological constraint. Cell 49, 369-378.

Palmiter, R. D., and Brinster, R. L. (1986). Germ-line transformation of mice. Ann. Rev. Genet. 20, 465-499.

Pinkert, C., Ornitz, D., Brinster, R. L., and Palmiter, R. D. (1987). An enhancer located 10kb upstream functions along with its promoter to direct efficient liver-specific expression in transgenic mice. Genes Dev. $1,268-278$.

Southern, E. M. (1975). Detection of specific sequences among DNA fragments separated by gel electrophoresis. J. Mol. Biol. 98, 503-517. Taramelli, R., Kioussis, D., Vanin, E., Bartram, K., Groffen, J., Hurst,

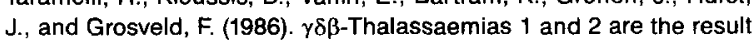
of a $100 \mathrm{kbp}$ deletion in the human $\beta$-globin cluster. Nucl. Acids Res. 14, 7017-7029.

Townes, T. M., Lingrel, J. B., Chen, H. Y., Brinster, R. L., and Palmiter, 
Position-Independent $\beta$-Globin Gene Expression

R. D. (1985). Erythroid-specific expression of human $\beta$-globin genes in transgenic mice. EMBO J. 4, 1715-1723.

Tuan, D., Solomon, W., Qiliang, L. S., and Irving, M. L. (1985). The " $\beta$-like-globin" gene domain in human erythroid cells. Proc. Natl. Acad. Sci. USA 32, 6384-6388.

Van der Ploeg, L. H. T., Konings, A., Oort, M., Roos, D., Bernini, L., and Flavell, R. A. (1980). $\gamma \beta$-Thalassaemia: deletion of the $\gamma$ - and $\delta$-genes influences $\beta$-globin gene expression in man. Nature 283, 637-642.

Wright, S., Rosenthal, A., Flavell, R. A., and Grusveld, F. (1984). DNA sequences required for regulated expression of $\beta$-globin genes in murine erythroleukemia cells. Cell 38, 265-273.

Zavodny, P., Roginsky, R., and Skoultchi, A. (1983). Regulated expression of human globin genes and flanking DNA in mouse erythroleukemia-human cell hybrids. In Globin Gene Expression and Hematopoietic Differentiation, G. Stamatoyannopoulos and A. Nienhuis, eds. (New York: Alan R. Liss, Inc.), pp. 53-62. 